\title{
Cell death in rat and mouse embryos exposed to methanol in whole embryo culture
}

\author{
B.D. Abbott*, M. Ebron-McCoy, J.E. Andrews \\ Developmental Toxicology Division, U.S. Environmental Protection Agency, Research Triangle Park, NC 277II, USA
}

Received 10 June 1994; accepted 31 August 1994

\begin{abstract}
Methanol induces developmental toxicity in rats and mice producing exencephaly, cleft palate, cervical skeletal defects, reduced body weight, and increased embryo/fetal death. Exposure to methanol in whole embryo culture also induces developmental retardation, dysmorphogenesis, and embryo lethality. In the present study, cultured rat and mouse embryos were exposed to methanol and subsequently observed for morphological effects and increased cell death using modified Feulgen staining which allowed nuclei throughout the embryo to be examined in situ. Growth and developmental scores were reduced by methanol in both rat and mouse embryos and the mouse embryos were affected at lower concentrations when compared to the rat. Methanol increased cell death in specific regions of both rat and mouse embryos, including the forebrain, the visceral arches, otic and optic placodes. These regions form derivatives which manifest morphological abnormalities following exposure in vivo. Methanol did not increase cell death in the neuroepithelium or neural folds and neural tube defects cannot be explained by excess cell death. The results of this study suggest that increased cell death in specific regions of the exposed embryos has a role in producing cranial malformations, abnormalities of the eye and ear, and cleft palate.
\end{abstract}

Keywords: Methanol; Developmental toxicity; Embryo culture

\section{Introduction}

Methanol is a developmental toxicant in rats and mice, inducing fetal weight reduction and malformations. This has been demonstrated following

\footnotetext{
Disclaimer: This paper has been reviewed by the Health Effects Research Laboratory, US Environmental Protection Agency, and approved for publication. Mention of trade names of commercial products does not constitute endorsement/recommendation for use.

* Corresponding author.
}

inhalation of methanol in the Sprague-Dawley rat at 5000-20 $000 \mathrm{ppm}$ methanol for $7 \mathrm{~h} /$ day on gestation days (GD) 1-19 (Nelson et al., 1985), and in CD-1 mice exposed to 1000-15000 ppm on GD 6-15 (Rogers et al., 1993). In the CD-1 mice, exposure to $5000 \mathrm{ppm}$ or higher induced cleft palate, exencephaly, sternebral defects, and cervical ribs and at $7500 \mathrm{ppm}$ or above embryo/fetal death increased. Also in CD-1, mice orally exposed twice daily to $2 \mathrm{~g} / \mathrm{kg}$ /day GD 6-15 produced comparable effects to a 7-h inhalation exposure at 10000 
ppm. Similarly, Long-Evans rats given a single oral methanol exposure (1.3-5.2 $\mathrm{ml} / \mathrm{kg}$ on GD 10) showed reduced fetal weight and increased incidence of malformations (Youssef et al., 1991).

Comparison of the rat and mouse studies suggests that the mouse is more sensitive to methanolinduced developmental toxicity. This is supported by whole embryo culture studies in which rat and mouse embryos were exposed in vitro to methanol across a range of concentrations (Andrews et al., 1993). Rat and mouse embryos at comparable developmental stages were exposed to methanol and in both species developmental retardation, dysmorphogenesis, and embryo lethality occurred with increasing concentration. The level of methanol required to produce effects in the mouse embryo $(4 \mathrm{mg} / \mathrm{ml})$ was lower than that required to produce comparable effects in the rat $(8 \mathrm{mg} / \mathrm{ml})$. In the mouse, embryotoxicity and morphological effects were induced at methanol levels which did not alter rat development.

The present study further characterizes the effects of methanol on cultured rat and mouse embryos and examines these embryos for increased cell death at sites of abnormal gross morphology. A modified Feulgen-staining procedure permitted morphological evaluation and visualization of nuclei within the embryo in situ by focusing through a whole-mounted specimen. Fragmented, condensed nuclei of dead cells were clearly distinguished from normal, interphase nuclei and various stages of mitosis could be recognized. Normal programmed cell death in the embryo was clearly observed in these embryos and increased cell death in specific tissues of methanol-exposed embryos was observed.

\section{Methods and materials}

\subsection{Animals}

Virgin female Sprague-Dawley rats obtained from Charles River Laboratories (Raleigh, NC) were mated overnight in our facilities. Pregnancy was confirmed the following morning by the presence of sperm in a vaginal smear and this was considered as gestational day (GD) 0. At GD 9.5, pregnant dams were anesthetized with ethyl ether and uteri were removed in order to prepare the embryos for whole embryo culture.
Pregnant female CD-1 mice (mated overnight to CD-1 male mice and presence of sperm confirmed by vaginal smear, sperm positive day $=$ GD 0 ) were obtained from Charles River Laboratories, Portage, MI. On GD 8, the pregnant mice were killed and uteri were removed to allow preparation of embryos for culture.

Both rats and mice were housed under controlled conditions of temperature $\left(72^{\circ} \pm 2^{\circ} \mathrm{F}\right)$, humidity $(40-60 \%)$, and lighting (12/12-h light/dark cycle) and provided food (Agway Rat, Mouse and Hamster 3000) and water ad libitum.

\subsection{Rat whole embryo culture}

Late head-fold stage embryos were explanted on GD 9.5 (0 somites). Embryos were dissected by a modification of the technique described by New (1978) and as described previously (Andrews et al., 1993). After removal of Reichert's membrane, those with intact yolk sacs were placed in culture bottles ( 2 embryos/bottle) containing $5 \mathrm{ml}$ of culture medium. Cultures were incubated at $37^{\circ} \mathrm{C}$ and bottles were rotated at $40 \mathrm{rev} . / \mathrm{min}$. Culture medium was male rat serum which was immediately centrifuged, heat-inactivated $\left(56^{\circ} \mathrm{C}\right.$ for $\left.30 \mathrm{~min}\right)$, filter sterilized, and supplemented with 50 units $/ \mathrm{ml}$ penicillin $\mathrm{G}$ and $50 \mu \mathrm{g} / \mathrm{ml}$ streptomycin. The culture medium was gassed initially for $3 \mathrm{~min}$ with $5 \%$ $\mathrm{O}_{2}, 5 \% \mathrm{CO}_{2}, 90 \% \mathrm{O}_{2}$ and the $\mathrm{pH}$ at the start of culture was 8.13. Methanol was added to the pregassed medium in the culture bottles at $0,8,12$, or $16 \mathrm{mg} / \mathrm{ml},(0,0.250,0.375$, and $0.499 \mathrm{M}$, respectively) as required by the protocol. Rat embryonic cultures were terminated at either 24 or 48 h. At 24 $\mathrm{h}$ the cultures to be terminated were removed and embryos were evaluated for growth and development, as described below. The embryos which were to remain in culture were transferred to fresh medium and were gassed for $2 \mathrm{~min}$ with $10 \% \mathrm{O}_{2}$, $5 \% \mathrm{CO}_{2}$, balance $\mathrm{N}_{2}$. Among the cultures continuing for $48 \mathrm{~h}$, some were exposed to methanol only during the first $24 \mathrm{~h}$ of culture (receiving control medium during the final $24 \mathrm{~h}$ ), while the remaining cultures had methanol added to the fresh medium and were thus exposed continuously for $48 \mathrm{~h}$. At $42 \mathrm{~h}$, cultures were gassed for $2 \mathrm{~min}$ with $20 \% \mathrm{O}_{2}$, $5 \% \mathrm{CO}_{2}$, balance $\mathrm{N}_{2}$. At $48 \mathrm{~h}$, the $\mathrm{pH}$ of the medium was measured and the embryos were removed and evaluated for viability by the presence of yolk 
sac circulation and heart beat. Viable embryos were assessed for growth by measurement of crown-rump length, (CR), head length (HL), and somite number (SN). The morphological scoring system developed by Brown and Fabro (1981) was used to further assess embryonic growth parameters as well as the developmental stage.

\subsection{Mouse whole embryo culture}

In a manner similar to that described for the rat, mouse embryos were removed on GD 8 (3-5 somites) and prepared for culture (Sadler, 1979; Sadler et al., 1986). Embryos were placed in culture for $24 \mathrm{~h}$ at $37^{\circ} \mathrm{C}$ in sealed $30-\mathrm{ml}$ serum bottles and rotated at $40 \mathrm{rev} . / \mathrm{min}$. Two embryos were placed in each bottle with $5 \mathrm{ml}$ of culture medium (75\% immediately centrifuged, heat-inactivated male rat serum, $25 \%$ Tyrodes salt solution filter sterilized and supplemented with antibiotics as detailed for rat embryos). Culture medium was gassed initially for $3 \mathrm{~min}$ with $5 \% \mathrm{O}_{2}, 5 \% \mathrm{CO}_{2}$, $90 \% \mathrm{~N}_{2}$, and methanol was added at $0,2,4$, or 8 $\mathrm{mg} / \mathrm{ml}(0,0.0624,0.1248$, and $0.250 \mathrm{M}$, respectively). Subsequent gassing for a $2-\mathrm{min}$ duration occurred at $5 \mathrm{~h}\left(5 \% \mathrm{O}_{2}, 5 \% \mathrm{CO}_{2}, 90 \% \mathrm{~N}_{2}\right)$ and $20 \mathrm{~h}$ $\left(10 \% \mathrm{O}_{2}, 5 \% \mathrm{CO}_{2}, 85 \% \mathrm{~N}_{2}\right)$. All embryonic mouse cultures were terminated at $24 \mathrm{~h}$ and the embryos evaluated as described for the rat cultures.

\subsection{Feulgen staining}

Cultured rat and mouse embryos were stained using a modified Feulgen nuclear staining protocol (Whiting, 1950; Abbott et al., 1990) for whole mounted tissues. A total of 37 rat and 70 mouse embryos were stained, representing all exposure levels and durations as described for each species. Kahle's fixative was prepared ( $17 \mathrm{ml} 95 \%$ ethanol, $6 \mathrm{ml} \mathrm{40 \%} \mathrm{formalin,} 2 \mathrm{ml}$ glacial acetic acid, $28 \mathrm{ml}$ water) and stored at room temperature until needed. After evaluation, the embryos were rinsed with PBS and placed in Kahle's fixative and kept at room temperature for at least $24 \mathrm{~h}$. Before staining, embryos were cut in half at the level of the heart and below the visceral arches, to give anterior and posterior pieces. The anterior portion was bisected in the dorsal-ventral plane using fine tip forceps to hold the embryo and a fine tapered blade scalpel. These cuts provided wholemounted, embryonic cranial and posterior tissues in which nuclei at all levels of the tissue could be viewed through the focal range of a standard binocular microscope. Embryos were washed twice in water for $10 \mathrm{~min}$ each, $1 \mathrm{~N} \mathrm{HCl}$ for $10 \mathrm{~min}$, incubated in fresh $1 \mathrm{~N} \mathrm{HCl}$ at $60-65^{\circ} \mathrm{C}$ for $15 \mathrm{~min}$. The Leuco-base Fuchsin (Feulgen Stain Detomasi, Carolina Biological Supply, Co., NC) incubation immediately followed for $35 \mathrm{~min}$. After washing with water, embryos were incubated for $15 \mathrm{~min} 2$ $X$ in triethylphosphate (Aldrich Chemical Co., NY), $1 \times$ in triethylphosphate/xylene (1:1) $15 \mathrm{~min}$, xylene $10 \mathrm{~min}$, and mounted on slides in a pool of Permount mounting medium (Fisher Laboratories, NJ). The stained embryos were examined to assess gross morphology, presence of mitotic figures, and localized patterns of cell death. Dead cells had dense, compact nuclei, which were frequently fragmented. The condensed chromatin of these cells was easily distinguishable from various stages of mitosis and normal interphase nuclei. The extent of cell death was scored (based on size of the area involved as well as frequency of condensed nuclei and fragments) as none $=0$, low $=1$, moderate $=2$, and high $=3$.

\subsection{Scanning electron microscopy}

Additional experiments were performed with both rat and mouse embryos to provide at least six embryos of each treatment group for scanning electron microscopy. The conditions for culture were as described and all methanol treatment levels and exposure durations were represented, except for the $16 \mathrm{mg} / \mathrm{ml}$ exposure of rat embryos. Embryos were prepared by standard methodology as described previously (Abbott and Birnbaum, 1989).

\subsection{Histology}

Rat embryos cultured for $48 \mathrm{~h}$ were fixed in 3\% paraformaldehyde, dehydrated by ethanolic series, and embedded in paraffin. These embryos were serially sectioned $(6 \mu \mathrm{m})$ and stained with hematoxylin. There were eight control embryos, 6 methanol-exposed embryos cultured at $8 \mathrm{mg} / \mathrm{ml}$, and six embryos exposed to $12 \mathrm{mg} / \mathrm{ml}$ for $48 \mathrm{~h}$.

\subsection{Data analysis}

All testing for the continuous variables was done within linear models, using SAS Proc GLM 
or Proc MIXED (SAS, 1985). The presence of differences among concentration groups was examined with $F$-tests in analyses of variance, and the pair-wise $t$-tests were used to test for differences between each methanol-exposed group and the control. Tests of significant trends were $F$-tests from linear regression models. Linear models using the predictor variables concentration, duration of exposure, duration of culture, and the in- teraction between exposure and culture were used to examine the effects of duration of exposure and culture on the outcome variables. Non-parametric statistical procedures were used to analyze the categorical variables. The analysis of the cell death data was performed on the mean of the left and right scores for each region. The Kruskal-Wallis test was used to test for differences among groups, and the Wilcoxon rank-sum test was used to
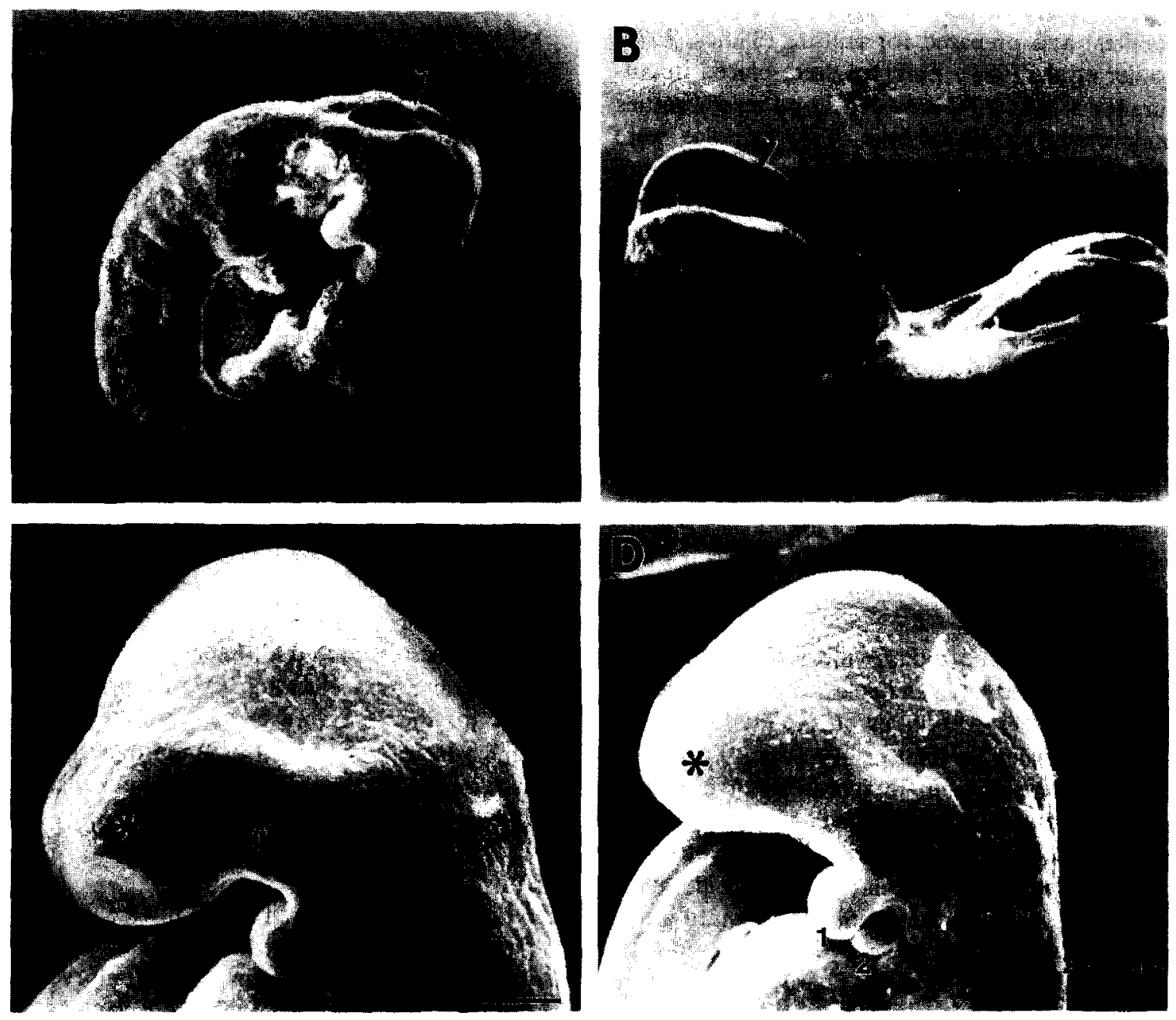

Fig. 1. Cultured rat embryos are shown after 24 (A and B) or 48 (C and D) hours in whole embryo culture. (A) The neural tube of an embryo cultured in control medium is in the process of fusing and remains open only in the hindbrain (arrowhead). (B) An embryo exposed to methanol at $12 \mathrm{mg} / \mathrm{ml}$ had not yet rotated and neural tube fusion was incomplete in cranial (arrowhead) and caudal regions. (C) An embryo cultured for $48 \mathrm{~h}$ in control medium has complete fusion of the neural tube, nasal placode invagination (below asterisk), and visceral arches (1 and 2). (D) The embryo exposed to methanol at $12 \mathrm{mg} / \mathrm{ml}$ has reduced forebrain (asterisk) and abnormal visceral arches. $(A-D$ scale bars $=250 \mu \mathrm{m}$ ). 
examine differences between each treated group and the control group. Fisher's exact test was used to examine pairwise differences for the dichotomous variables. Concentration-related trends

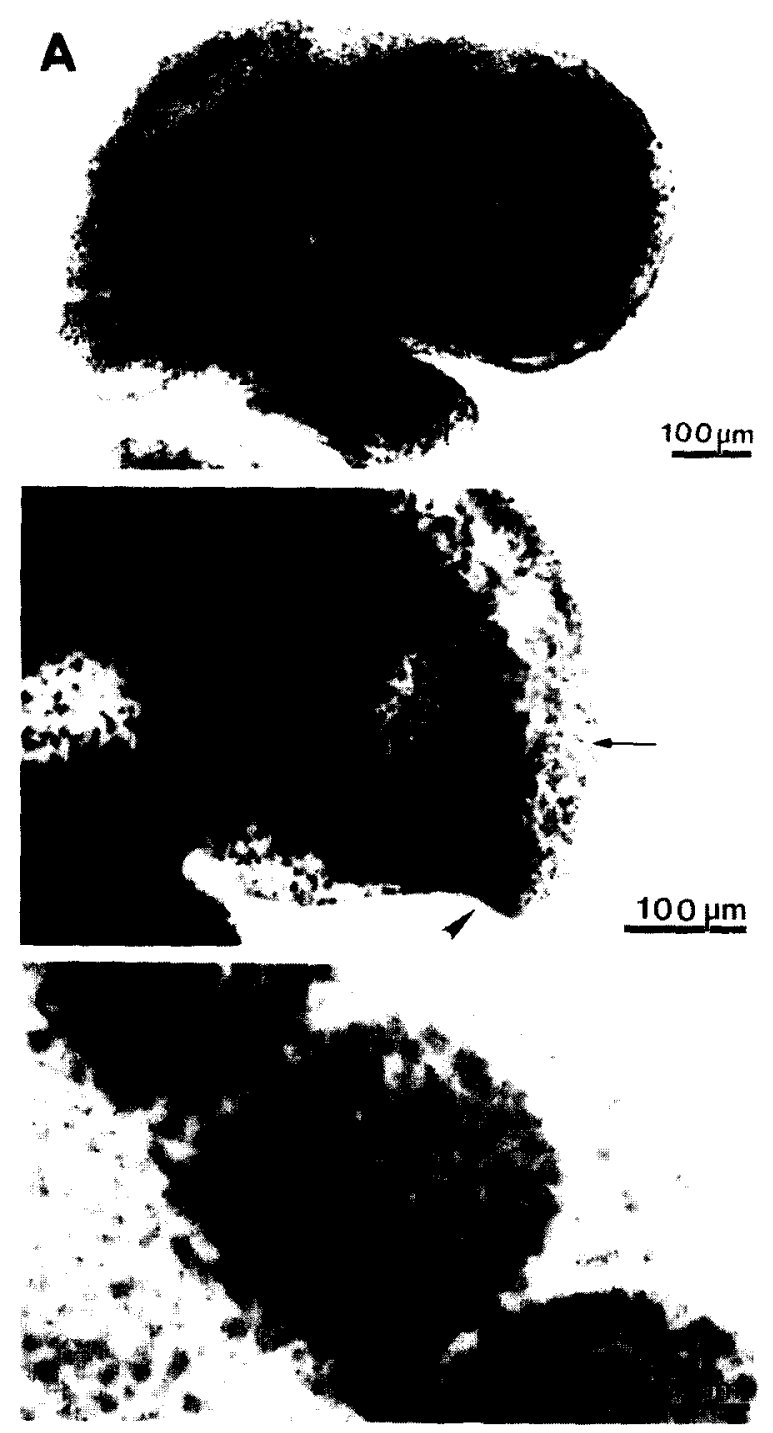

Fig. 2. The Feulgen-stained rat embryos also show the effects of methanol exposure following $24 \mathrm{~h}$ in culture. The control embryo (A) has a well-rounded, large forebrain region and well-developed first arch [1], but the embryo exposed to methanol at $12 \mathrm{mg} / \mathrm{ml}$ (B) has cell death along the anterior region (arrow) and deficiencies in the region adjacent to the optic placode (arrowhead). (C) These are somites of a control embryo which illustrate the utility of Feulgen staining for visualizing the nuclei in mitosis and abundance of mitotic figures in the cultured embryos. (Scale bars as shown). were tested with Jonckheere's test. Partial Spearman rank correlations were calculated to test for an association between duration of culture and duration of methanol exposure with each outcome variable, while adjusting for the concentration effect.

\section{Results}

\subsection{Rat embryonic growth and development}

Rat embryonic growth and morphology were examined after 24 and $48 \mathrm{~h}$ in culture. At $24 \mathrm{~h}$ anterior neural tube closure was advanced in control embryos (Fig. 1A) and in many cases was complete. The first visceral arch was well formed (Figs. 1A and 2A) and generally 11-12 somites were present (Table 1). Mitotic figures were easily identified and abundant in all tissues throughout the embryo (as shown for somites in Fig. 2C). In control embryos, dead cells were generally infrequent, but were noted in forebrain and optic placode (Table 2). Embryos exposed to methanol showed a concentration-related trend for decreased yolk sac diameter, developmental score $(P<$ $0.05)$, and somite number $(P<0.01)$. The decrease in somite number at $12 \mathrm{mg} / \mathrm{ml}$ was significant compared to control $(P<0.01)$. Neural tube closure of treated embryos (Fig. 1B) lagged behind that of controls and head shape was abnormal for many of these embryos (Fig. 2B). This is reflected in the significant $(P<0.05)$ trend toward lower developmental score for methanol-exposed groups and an increase in \% abnormal (although not statistically significant the methanol-exposed had $25 \%$ abnormal vs. $0 \%$ in controls). Anomalies observed were primarily delayed development, erratic neural seam, open neural tube, rotational defects and abnormal brain development. An almost complete absence of dead cells was noted in the elevated neural folds of the unfused neural tube of methanol-exposed embryos. Mitotic activity and cell death in the neuroepithelium of methanolexposed embryos appeared comparable to those observed for controls.

After $48 \mathrm{~h}$ in culture the control embryos had completed neural tube fusion. The second visceral arch and otic placode were present and well formed. Relative to the $24 \mathrm{~h}$ observations, these em- 


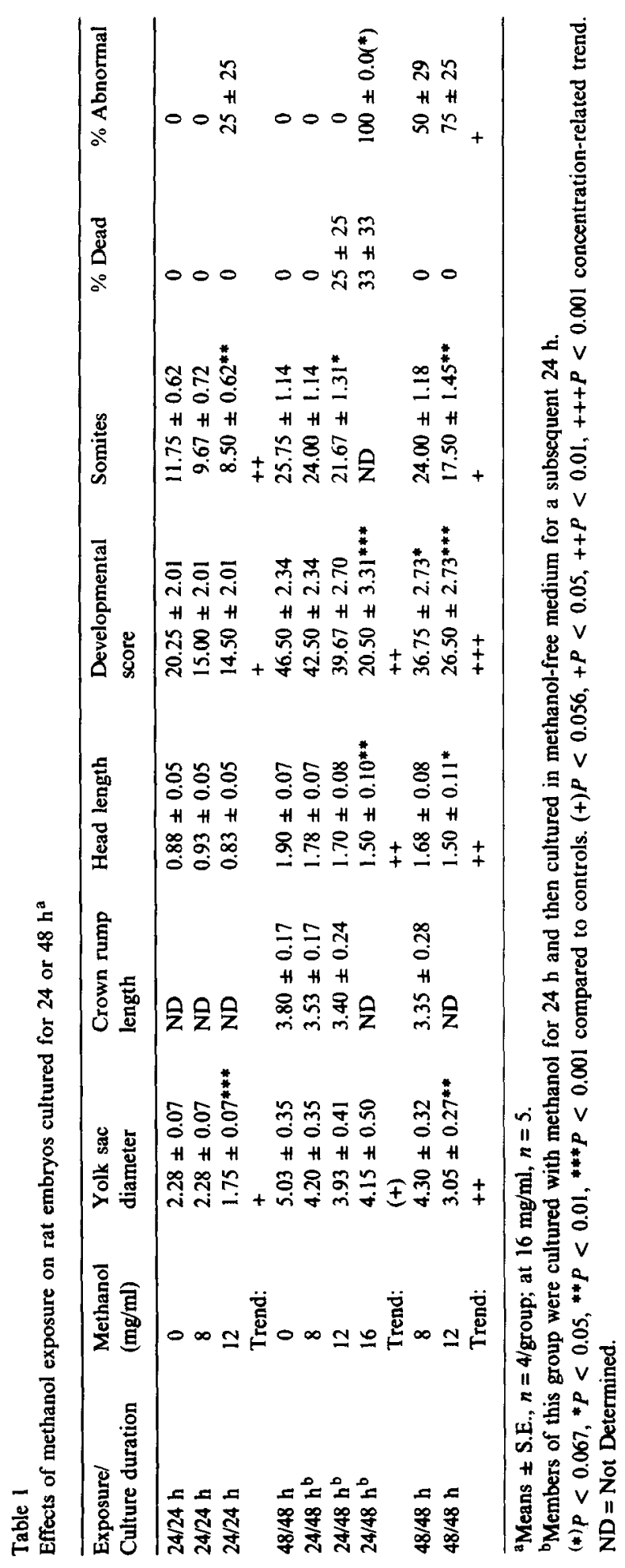


bryos showed increased yolk sac diameter, head length, developmental scores, and numbers of somites (Table 1). The general morphology of these embryos is shown in Figs. $1 \mathrm{C}$ and $3 \mathrm{~A}$. In control embryos after $48 \mathrm{~h}$ of culture, a low to moderate level of cell death was observed at the bases of the visceral arches and in the otic placode as well as among the surrounding cells (Table 2, and Fig. 3C). Mitotic activity remained high in the neuroepithelial cells, somites, visceral arches, otic and optic placodes. The neuroepithelium showed a high degree of mitotic activity in the cells adjacent to the brain ventricle. Dead cells were rare in this tissue (Fig. 4A).

The embryos exposed to methanol only during the first $24 \mathrm{~h}$ of a 48-h culture showed a trend toward decreased yolk sac diameter (Table 1, $P=0.056)$, head length and somite number $(P<$ $0.01)$. Head length after $16 \mathrm{mg} / \mathrm{ml}$ and somite number after $12 \mathrm{mg} / \mathrm{ml}$ were significantly $(P<0.01$ and $<0.05$, respectively) decreased relative to control values. The developmental scores were significantly decreased in a concentration-related trend $(P<0.01)$, and at $16 \mathrm{mg} / \mathrm{ml}$ the reduction was significant relative to controls $(P<0.001)$.
The highest concentration produced abnormalities in $100 \%$ of the embryos and there were significant concentration-related increases in cell death in visceral arches 1 and 2 and in the otic placode ( $P$ $<0.05,<0.01,<0.01$, respectively).

Continuous exposure to methanol for $48 \mathrm{~h}$ decreased yolk sac diameter, head length, somite number, and developmental scores, and increased the $\%$ abnormal (Table 1). At $12 \mathrm{mg} / \mathrm{ml}$, the effects on growth (yolk sac diameter, head length, somite number) were significantly reduced relative to control $(P<0.01,0.05$, and 0.01 , respectively) and a concentration-related trend occurred for each parameter $(P<0.01, P<0.01, P<0.05$, respectively). The developmental score was significantly reduced at both 8 and $12 \mathrm{mg} / \mathrm{ml}$ relative to control and a significant concentration-related trend also occurred. The effects on cranial morphology can be seen in Figs. 1D and 3B, where forebrain was drastically reduced and visceral arches were small and abnormally positioned. The highest concentration of methanol $(16 \mathrm{mg} / \mathrm{ml})$ significantly increased the incidence of cell death in all regions relative to controls (Table 2, $P<0.05$; Fig. 3D). At $12 \mathrm{mg} / \mathrm{ml}$ the level of cell death increased

Table 2

Rat whole embryo culture: incidence of cell death ${ }^{a}$

\begin{tabular}{|c|c|c|c|c|c|c|}
\hline $\begin{array}{l}\text { Exposure/ } \\
\text { Culture } \\
\text { duration }\end{array}$ & $\begin{array}{l}\text { Methanol } \\
(\mathrm{mg} / \mathrm{ml})\end{array}$ & Forebrain & Optic placode & $\begin{array}{l}\text { Visceral arch } \\
\text { No. } 1\end{array}$ & $\begin{array}{l}\text { Visceral arch } \\
\text { No. } 2\end{array}$ & Otic placode \\
\hline $24 / 24 \mathrm{~h}$ & 0 & $1.00 \pm 1.00$ & $0.33 \pm 0.58$ & $0.00 \pm 0.00$ & ND & ND \\
\hline $24 / 24 \mathrm{~h}$ & 8 & $1.00 \pm 0.82$ & $0.00 \pm 0.00$ & $0.25 \pm 0.29$ & ND & ND \\
\hline $24 / 24 \mathrm{~h}$ & $\begin{array}{l}12 \\
\text { Trend: }\end{array}$ & $1.33 \pm 0.58$ & $0.25 \pm 0.50$ & $0.25 \pm 0.50$ & ND & ND \\
\hline $48 / 48$ h & 0 & $0.13 \pm 0.25$ & $0.13 \pm 0.25$ & $1.13 \pm 0.48$ & $1.00 \pm 0.41$ & $0.88 \pm 0.48$ \\
\hline $24 / 48 h^{b}$ & 8 & $0.17 \pm 0.29$ & $0.00 \pm 0.00$ & $1.17 \pm 1.04$ & $1.33 \pm 0.58$ & $2.00 \pm 1.00$ \\
\hline $24 / 48 h^{b}$ & 12 & $0.17 \pm 0.29$ & $0.33 \pm 0.29$ & $1.67 \pm 0.76$ & $2.17 \pm 0.58$ & $2.33 \pm 0.29^{*}$ \\
\hline $24 / 48 h^{b}$ & $\begin{array}{l}16 \\
\text { Trend: }\end{array}$ & $0.75 \pm 0.35$ & $0.25 \pm 0.35$ & $\begin{array}{l}2.50 \pm 0.71 \\
+\end{array}$ & $\begin{array}{l}3.00 \pm 0.00 \\
++\end{array}$ & $\begin{array}{l}2.50 \pm 0.71 \\
++\end{array}$ \\
\hline $48 / 48 \mathrm{~h}$ & 8 & $0.50 \pm 1.00$ & $0.25 \pm 0.29$ & $2.13 \pm 0.63$ & $2.00 \pm 0.91$ & $1.13 \pm 0.63$ \\
\hline $48 / 48 \mathrm{~h}$ & 12 & $0.63 \pm 0.63$ & $0.88 \pm 0.75$ & $1.88 \pm 0.48$ & $2.38 \pm 0.75^{*}$ & $2.50 \pm 0.58^{*}$ \\
\hline $48 / 48 \mathrm{~h}$ & $\begin{array}{l}16 \\
\text { Trend: }\end{array}$ & $\begin{array}{l}1.50 \pm 0.41^{*} \\
++\end{array}$ & $\begin{array}{l}1.50 \pm 0.41^{*} \\
++\end{array}$ & $\begin{array}{l}2.38 \pm 0.48^{*} \\
++\end{array}$ & $\begin{array}{l}2.63 \pm 0.48^{*} \\
++\end{array}$ & $\begin{array}{l}2.38 \pm 0.48^{*} \\
++\end{array}$ \\
\hline
\end{tabular}

${ }^{a}$ Values are means \pm S.E.

bThe members of this group were cultured with methanol for $24 \mathrm{~h}$ and then cultured in methanol-free medium for a subsequent $24 \mathrm{~h}$. ${ }^{*} P<0.05$ compared to controls. ${ }^{+} P<0.05,{ }^{++} P<0.01$ concentration-related trend.

ND, not determined as structure not present at this stage of development. 

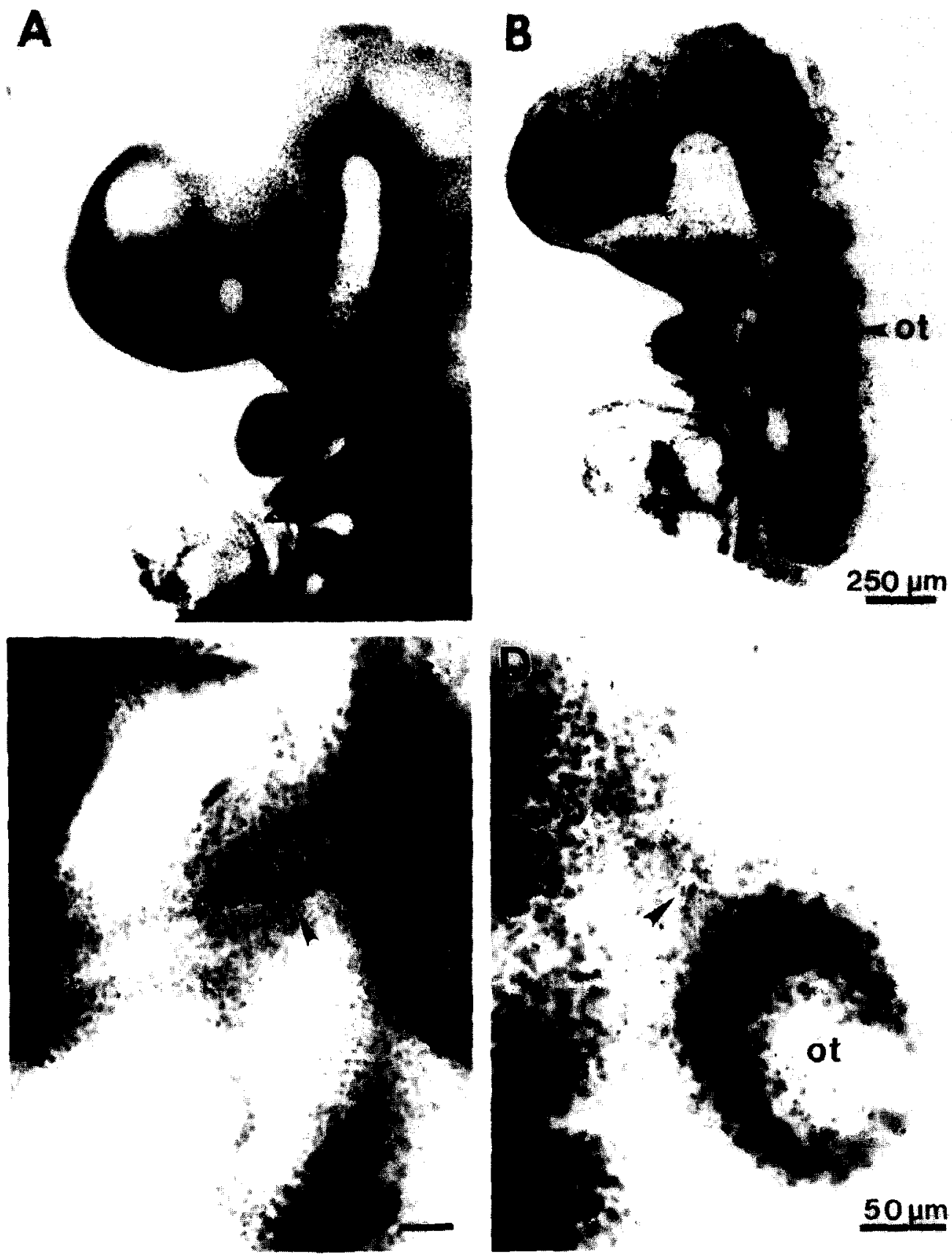

Fig. 3. Feulgen stained rat embryos cultured for $48 \mathrm{~h}$ in control medium (A and C) or with methanol (B, $12 \mathrm{mg} / \mathrm{ml} ; \mathrm{D}, 16 \mathrm{mg} / \mathrm{ml}$ ) are shown to allow comparison of morphology and cell death in the region of the 2nd visceral arch and otic placode. The methanolexposed (B) embryo has severe, multiple cranial dysmorphologies. Cell death (arrowhead) occurred at a low level in the control embryo (C) adjacent to the base of the second visceral arch (2) and near the otic placode (ot). After methanol exposure for $48 \mathrm{~h}$ (D), large numbers of fragmented nuclei (arrowhead) were observed adjacent to and within the otic placode. (A and B scale bars $=250$ $\mu \mathrm{m} ; \mathrm{C}$ and $\mathrm{D}=50 \mu \mathrm{m})$. 


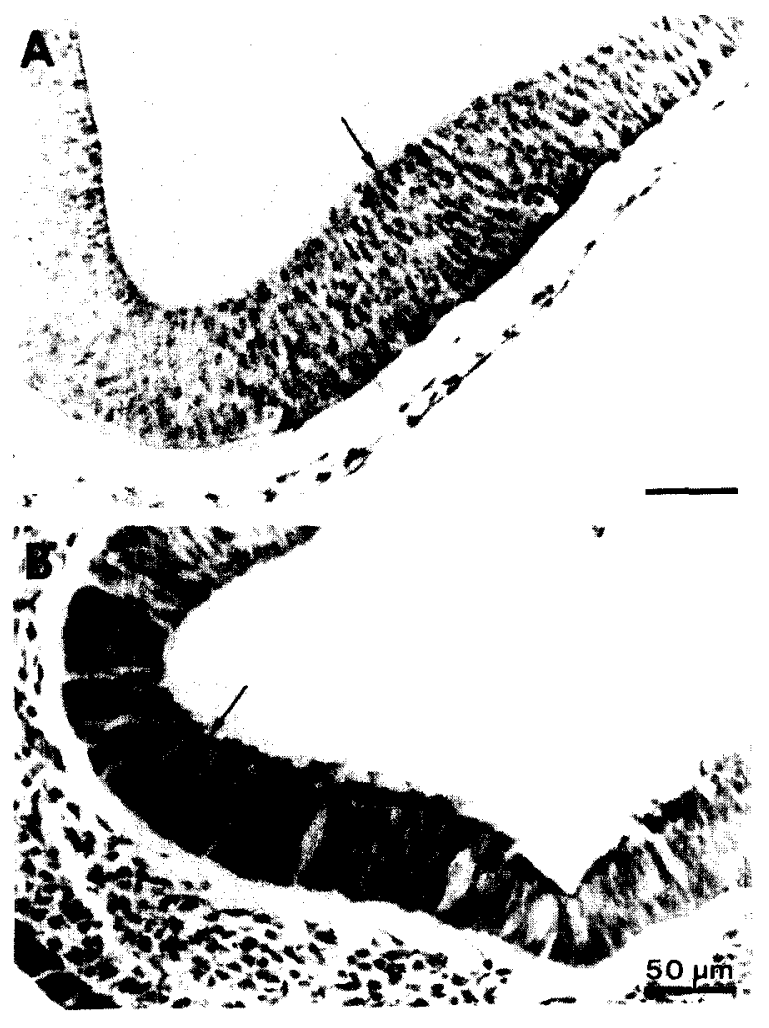

Fig. 4. Histological sections are shown of the neuroepithelium of control (A) and methanol-exposed (B, $8 \mathrm{mg} / \mathrm{ml}$ ) embryos following $48 \mathrm{~h}$ in culture. There was a high level of mitosis (arrows) among the basal cells near the ventricle in both control and treated embryos and there was no difference in numbers of dead cells, which were rare in this region. (A and B scale bar $=50 \mu \mathrm{m})$.

significantly in visceral arch 2 and in the otic placode relative to control levels, $(P<0.05)$. The level of cell death in forebrain, optic placode, visceral arches 1 and 2 , and the otic placode all showed a significant concentration-related trend $(P<0.01)$. However, as was the case at $24 \mathrm{~h}$, the neural tube defects were not associated with increased cell death or apparent reduction in mitosis (Fig. 4B).

There was a significant association between incidence of abnormalities and duration of methanol exposure $(P<0.05)$. Exposure to 8 or $12 \mathrm{mg} / \mathrm{ml}$ only during the first $24 \mathrm{~h}$ of culture did not produce a significant increase in abnormalities (Table 1), however, continuous exposure for $48 \mathrm{~h}$ at these levels affected 50 and $75 \%$ of the embryos, respectively. Similarly, the extent of cell death in the optic placodes increased with length of exposure (Table 2, $P<0.01$ ).

\subsection{Mouse embryonic growth and development}

Embryonic mice were cultured for $24 \mathrm{~h}$ and reached a stage of development (Figs. 5A and 6A) similar to that achieved by the rat embryos at the end of the 48-h culture period. The concentration of methanol required to disrupt development was lower than that used for the rat cultures (Table 3). Methanol exposure significantly decreased yolksac diameter $(P<0.003)$, crown-rump length, head length, somite number, and developmental score in a concentration-related manner $(P<$ 0.001). A significant concentration-related increase in abnormalities occurred as methanol concentrations increased from 2 to $8 \mathrm{mg} / \mathrm{ml}(P<$ $0.001)$. At the highest concentration $(8 \mathrm{mg} / \mathrm{ml})$, the effects on crown rump length, head length, developmental score, somite number, and $\% \mathrm{ab}$ normal were significant relative to controls $(P<$ 0.05 and $P<0.001$ ). The cranial abnormalities in the mouse embryo were similar to those observed in the rat embryos and included reduced forebrain, visceral arch abnormalities, and neural tube defects (Figs. 5B and 6B).

Detecting methanol-induced cell death was more difficult in the mouse embryo due to the relatively high incidence of region-specific cell death in the controls. In controls, dead cells were localized to bases of the visceral arches (Fig. 6C), the otic placode and its adjacent cells, with little or no cell death in the optic placode and neuroepithelium. Overall, the cultured mouse embryos appeared to have more cell death in these regions than similarly staged rat embryos cultured for 48 h. However, effects of methanol were detected in the basal regions of visceral arches 1 and 2 where a significant concentration-related trend for increased cell death was detected (Fig. 6D, Table 4, $P<0.05$ ). The trigeminal placode also appeared reduced in size, abnormally shaped, and had elevated cell death. At the highest concentration (8 $\mathrm{mg} / \mathrm{ml}$ ), areas of dead cells were observed in the optic placode and half of this treatment group had morphologically abnormal optic placodes. The 

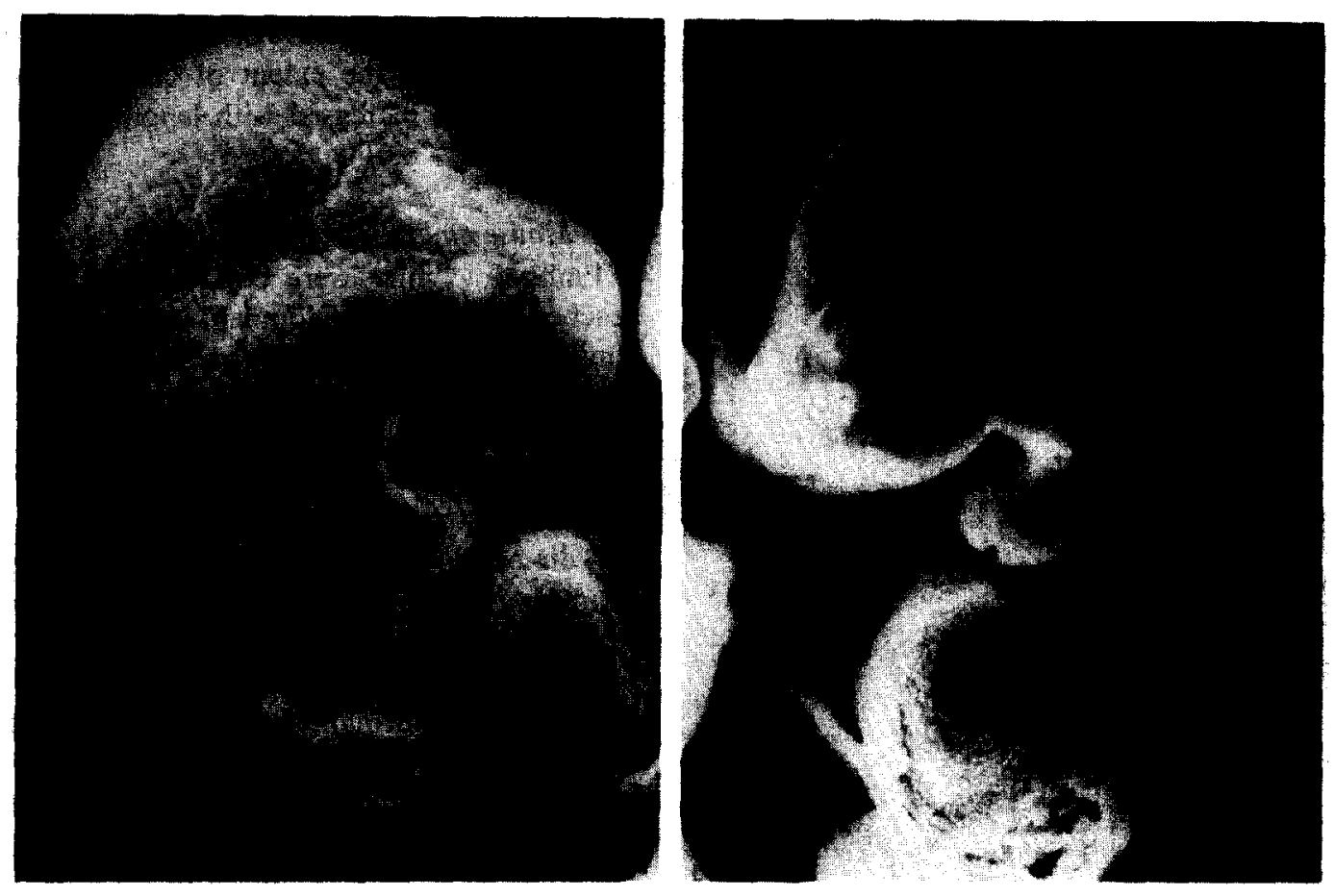

Fig. 5. The mouse embryo cultured for $24 \mathrm{~h}$ in control medium (A) had complete fusion of the neural tube and 3 visceral arches (1,2,3) were observed. Exposure to methanol at $8 \mathrm{mg} / \mathrm{ml}(B)$ resulted in an open neural tube (asterisk) and reduced forebrain and visceral arch abnormalities. (A and B scale bar $=250 \mu \mathrm{m}$ ).

embryos with open neural tubes had no cell death in the neuroepithelial cells and mitotic activity did not decrease relative to other regions of the embryo.

\section{Discusesion}

Methanol exposure in whole embryo culture affected growth and development of both rat and mouse embryos in a concentration-dependent manner. These findings are in agreement with previously published data and the developmental scores, percent abnormal, and effects of methanol on growth parameters are almost identical to those of the earlier study (Andrews et al., 1993). In addition, the present study provides information regarding the time-course of methanol-induced responses. Effects of methanol on growth and development were detected in the rat embryos following $24 \mathrm{~h}$ of methanol exposure and became more pronounced by the end of a 48-h culture. However, significant trends were present within 24 $\mathrm{h}$ and persisted even if the last $24 \mathrm{~h}$ of culture was a 'recovery' period in control medium.

Methanol exposure increased cell death relative to controls and this effect was region and developmental-stage specific. The affected areas were similar in rat and mouse and included forebrain, optic placode, visceral arches 1 and 2, and the otic placode. These developing tissues exhibit physiological or programmed cell death and this was observed in the control embryos. It is particularly noteworthy that the regions with methanol-enhanced cell death also exhibited morphological abnormalities following in vivo exposure. After in vivo methanol exposure, abnormalities observed in near-term fetuses included microcephaly, narrowed head, stunted visceral arches, occular anomalies, and otic ossicle malformations (Bolon et al., 1994). Rat embryos exposed 

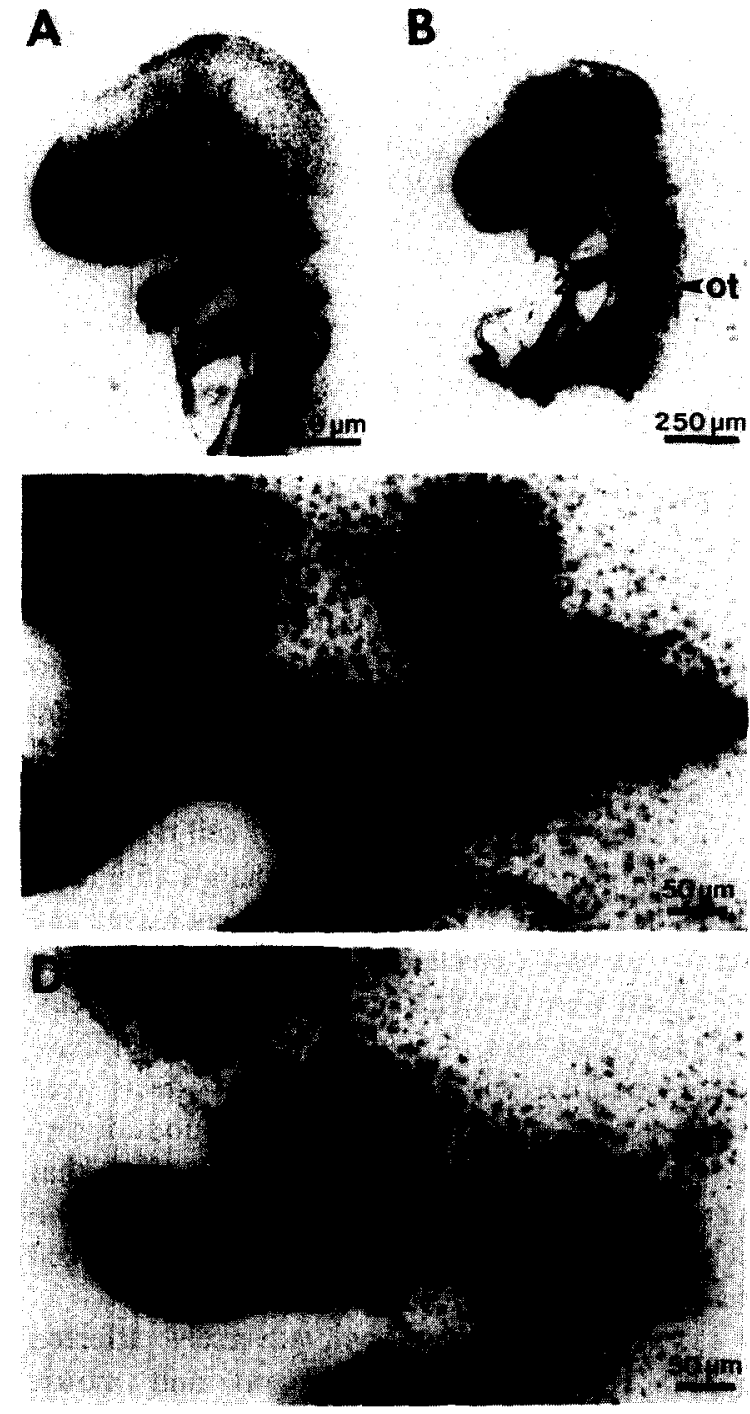

Fig. 6. When compared to a control embryo (A), the morphological effects of methanol exposure at $8 \mathrm{mg} / \mathrm{ml}$ can be seen in the Feulgen-stained embryo (B). The reduction in overall embryonic growth and the effects on cranial morphology are apparent, including reduction in forebrain, abnormal first visceral arch placement and shape, and incomplete formation of the otic vessicle (ot). (C) The trigeminal placode (asterisk) at the base of the first visceral arch of the control showed small numbers of fragmented nuclei of dead cells (arrowheads) in the placode and between this structure and the arch. (D) Exposure to $8 \mathrm{mg} / \mathrm{ml}$ reduced the size of the first visceral arch, reduced the size of the trigeminal placode, and increased the cell death in this region. (Scale bars as shown). by various routes in vivo exhibit micro-opthalmia, abnormal lens (single oral exposure, Youssef et al., 1991), exophthalmia and anopthalmia (inhalation, Nelson et al., 1985). The increased cell death observed at the base of the visceral arches may contribute to their hypoplasia and be related to the malformations observed in structures which are derived from the visceral arches, including the mandible, maxilla, and secondary palate. Induction of cleft secondary palate by methanol may be related to the increased cell death observed in the basal region of the first visceral arch. CD-1 mouse embryos examined on GD 15 following in vivo inhalation exposure (10 000 ppm methanol, $7 \mathrm{~h} /$ day GD 6-15) had small palatal shelves which were also unelevated in some embryos (Abbott et al., 1994). The primary cause of clefting appears related to small visceral arches and although cell death may contribute to the hypoplasia, other responses which could produce this effect include decreased mitosis and/or insufficient migration of neural crest cells.

The methanol-induced cell death in regions where programmed cell death normally plays a morphogenetic role resembles patterns of ethanolinduced enhanced cell death (Sulik et al., 1988; Kotch and Sulik, 1992a,b). Ethanol induces craniofacial defects which have been extensively studied both in vivo (Webster et al., 1980) and in vitro (Brown et al., 1979; Priscott, 1982; Wynter et al., 1983) and the resulting cranial malformations are a part of the fetal alcohol syndrome (Abel, 1984). Embryonic mice exposed to ethanol either in vivo or in vitro had increased levels of cell death in the neuroepithelium. The craniofacial and neural tube defects induced by ethanol were in part attributed to excessive cell death in specific embryonic tissues. Neural tube defects are also induced in rats and mice by methanol, however, excess cell death was not detected in the present study in the elevated neural folds or in neuroepithelial cells. This confirms data from a study in which Nile blue sulfate staining did not detect differences in cell death between control and methanol-exposed mouse embryos on GD 8.5-9.5, even though exencephaly was induced (Bolon et al., 1994). That staining method is limited by the depth to which the dye can penetrate 
Table 3

Effects of methanol on mouse embryos cultured for $24 \mathrm{~h}$ and evaluated on gestation day 9

\begin{tabular}{llllllll}
\hline $\begin{array}{l}\text { Methanol } \\
(\mathrm{mg} / \mathrm{ml})\end{array}$ & $\begin{array}{l}\text { Yolk sac } \\
\text { diameter }\end{array}$ & $\begin{array}{l}\text { Crown rump } \\
\text { length }\end{array}$ & Head length & $\begin{array}{l}\text { Developmental } \\
\text { score }\end{array}$ & Somites & $\begin{array}{l}\% \\
\% \\
\text { Dead }\end{array}$ & $\begin{array}{l}\% \\
\text { Abnormal }\end{array}$ \\
\hline 0 & $3.48 \pm 0.17$ & $2.68 \pm 0.06$ & $1.35 \pm 0.07$ & $40.91 \pm 2.04$ & $21.37 \pm 0.99$ & $6 \pm 6$ & $18 \pm 10$ \\
2 & $3.29 \pm 0.17$ & $2.61 \pm 0.06$ & $1.27 \pm 0.07$ & $38.39 \pm 1.97$ & $20.00 \pm 0.96$ & 0 & $17 \pm 9$ \\
4 & $3.54 \pm 0.17$ & $2.70 \pm 0.06$ & $1.23 \pm 0.07$ & $38.72 \pm 1.97$ & $20.77 \pm 1.04$ & 0 & $50 \pm 12$ \\
8 & $3.07 \pm 0.17$ & $2.29 \pm 0.08^{* *}$ & $1.10 \pm 0.07^{*}$ & $29.69 \pm 2.04^{* *}$ & $18.50 \pm 0.99^{*}$ & 0 & $94 \pm 6^{*}$ \\
Trend: & + & ++ & ++ & ++ & ++ & ++ \\
\hline
\end{tabular}

$N=17-18$ embryos/group.

${ }^{+} \mathrm{P}<0.003{ }^{++} P<0.001$ concentration-response trend; ${ }^{*} P<0.05,{ }^{* *} P<0.001$ compared to controls.

the tissues, while the Feulgen stain applied in the present study allowed examination of the tissues throughout the entire embryo.

Methanol and ethanol both appear to increase cell death in regions where programmed cell death occurs. However, the regions which are affected differ between the two alcohols. Ethanol induced cell death in the neural folds and this correlates with neural tube defects. Methanol induces neural tube defects but there is no evidence for cell death in those structures playing a role in producing that lesion. However in the present observations, the increased cell death in regions which rely on neural crest cells for morphogenesis correlates with malformations of these structures. The neural crest cells and their derivatives appear to be more sensitive to methanol than cells with other embryonic lineages. The culture period for both rat and mouse embryos encompasses the period (0-16 somite stage) in which neural crest cells migrate from the hindbrain, midbrain, and forebrain to their respective ventral embryonic destinations

Table 4

Mouse whole embryo culture: cell death scores ${ }^{a}$

\begin{tabular}{lll}
\hline $\begin{array}{l}\text { Methanol } \\
(\mathrm{mg} / \mathrm{ml})\end{array}$ & $\begin{array}{l}\text { Visceral arch } \\
\text { No. 1 }\end{array}$ & $\begin{array}{l}\text { Visceral arch } \\
\text { No. 2 }\end{array}$ \\
\hline 0 & $2.40 \pm 0.55$ & $1.00 \pm 0.71$ \\
2 & $2.17 \pm 0.26$ & $1.25 \pm 0.42$ \\
4 & $2.67 \pm 0.41$ & $1.42 \pm 0.49$ \\
8 & $2.92 \pm 0.20$ & $1.75 \pm 0.69$ \\
Trend: & + & + \\
\hline
\end{tabular}

${ }^{a}$ Mean \pm standard error.

${ }^{+} P<0.05$, concentration-response trend.
(Serbedzija et al., 1992). In the mouse embryo the last group of crest cells to migrate is in the forebrain and this migration is completed at approximately the 16 somite stage. In the rat and mouse embryo the neural crest cells migrate into the visceral arches, trigeminal placode, and forebrain, all regions in which methanol increased cell death in our in vitro studies.

In rat embryos, the incidence of cell death was not significantly increased by methanol after $24 \mathrm{~h}$ of exposure. The regionally specific increased cell death was only detected after $48 \mathrm{~h}$ in culture and the effects were present even if the final $24 \mathrm{~h}$ of culture was with control medium, a 'recovery' phase for methanol-exposed embryos. The effects were more severe if the exposure was continuous during the entire 48-h culture. These data suggest that methanol exerts a toxic effect during the first $24 \mathrm{~h}$ of exposure which is later manifested as excess cell death.

In summation, methanol adversely affected growth and development of rat and mouse embryos in vitro. The neural tube defects and early responses to methanol appear to be mediated through mechanisms other than cell death. Abnormalities of forebrain, visceral arches, otic and optic placode were associated with increased cell death suggesting that excessive cell death may have a role in inducing malformations in these structures.

\section{Acknowledgements}

J. Schmid provided valuable statistical advice and expertise in performing the analyses for this 
study. The Feulgen staining procedures were performed by T.S. Wilke. H. Nichols provided valuable assistance with embryonic culture procedures.

\section{References}

Abbott, B.D., Logsdon, T.R. and Wilke, T.S. (1994) Effects of methanol on embryonic mouse palate in serum-free organ culture. Teratology 49, 122-134.

Abbott, B.D., Hill, L.G. and Birnabum, L.S. (1990) Processes involved in retinoic acid production of small palatal shelves and limb defects. Teratology 41, 299-310.

Abbott, B.D. and Birnbaum, L.S. (1989) TCDD alters medial epithelial cell differentiation during palatogenesis. Toxicol. Appl. Pharmacol. 99, 276-286.

Abel, E.L. (1984) Fetal Alcohol Syndrome and Fetal Alcohol Effects. Plenum Publishing Corporation, New York.

Andrews, J.E., Ebron-McCoy, M., Logsdon, T.R., Mole, L.M., Kavlock, R.J. and Rogers, J.M. (1993) Developmental toxicity of methanol in whole embryo culture: A comparative study with mouse and rat embryos. Toxicology 81 , 205-215.

Bolon, B., Welsch, F. and Morgan, K.T. (1994) Methanolinduced neural tube defects in mice: pathogenesis during neurulation. Teratology 49, 497-517.

Brown, N.A. and Fabro, S. (1981) Quantitation of rat embryonic development in vitro: a morphological scoring system. Teratology 24, 65-78.

Brown, N.A., Goulding, E.H. and Fabro, S. (1979) Ethanol embryotoxicity: direct effects on mammalian embryos in vitro. Science 206, 573-575.

Kotch, L.E. and Sulik, K.K. (1992a) Experimental fetal alcohol syndrome: proposed pathogenic basis for a variety of associated facial and brain anomalies. Am. J. Med. Genet. 44, 168-176.

Kotch, L.E. and Sulik. K.K. (1992b) Patterns of ethanolinduced cell death in the developing nervous system of mice; neural fold states through the time of anterior neural tube closure. Int. J. Dev. Neurosci. 10, 273-279.

Nelson, B.K., Brightwell, W.S., MacKenzie, D.R., Khan, A., Burg, J.R., Weigel, W.W. and Goad, P.T. (1985)
Teratological assessment of methanol and ethanol at high inhalation levels in rats. Fundam. Appl. Toxicol. 5, 727-736.

New, D.A.T. (1978) Whole-embryo culture and the study of mammalian embryos during organogenesis. Biol. Rev. 53, 81-122.

Priscott, P.K. (1982) The effects of ethanol on rat embryos developing in vitro. Bicohem. Pharmacol. 31, 3641-3643.

Rogers, J.M., Mole, L.M., Chernoff, N., Barbee, B.D., Turner, C.I., Logsdon, T.R. and Kavlock, R.J. (1993) The developmental toxicity of inhaled methanol in the CD-1 mouse, with application of quantitative dose-response modeling for estimation of benchmark dosages. Teratology 47, 175-188.

Sadler, T.W. (1979) Culture of early somite mouse embryos during organogenesis. J. Embryol Exp. Morphol. 49, 17-25.

Sadler, T.W., Phillips, L.S., Balkan, L. and Goldstein, S. (1986) Somatomedin inhibitors from diabetic rat serum alter growth and development of mouse embryos in culture. Diabetes 35, 861-865.

SAS Institute, Inc., SAS User's Guide: Statistics, Version 5 Edition. (1985) Cary, NC: SAS Institute, Inc.

Serbedzija, G.N., Bronner-Fraser, M. and Fraser, S.E. (1992) Vital dye analysis of cranial neural crest cell migration in the mouse embryo. Development 116, 297-307.

Sulik, K.K., Cook, C.S. and Webster, W.S. (1988) Teratogens and craniofacial malformations: relationships to cell death. Development 103 suppl., 213-232.

Webster, W.S., Walsh, D.A., Lipson, A.H. and McEwen, S.E. (1980) Teratogenesis after acute alcohol exposure in inbred and outbred mice. Neurobehav. Toxicol. 2, 227-234.

Whiting, A.R. (1950) A modification of the Schmuck-Metz whole mount technic for chromosome study. Stain Technol. $25,21-22$

Wynter, J.M., Walsh, D.A., Webster, W.S., McEwen, S.E. and Lipson, A.H. (1983) Teratogenesis after acute alcohol exposure in cultured rat embryos. Teratogen. Carcinogen. Mutagen. 3, 421-428.

Youssef, A.F., Baggs, R.B., Weiss, B. and Miller, R.K. (1991) Methanol teratogenicity in pregnant Long-Evans rats. Teratology 43, 467. 